\title{
PANCASILA DALAM PERSPEKTIF HUKUM KONSTITUSI INDONESIA
}

\author{
Fadli Andi Natsif \\ Universitas Islam Negeri (UIN) Makassar \\ Email : fadlianfa@yahoo.com
}

\begin{abstract}
In the perspective of constitutional law, the affirmation of Pancasila as the basis and ideology of the nation and state of Indonesia is very clearly embodied in the Preamble of the 1945 Constitution. It is not necessary to be poured through the Act or MPR Tap, whose position can be changed someday and even abolished. Thus, the recognition of Pancasila's very firm and clear position brings the consequence that Pancasila must also function as a guideline (base and direction) in preparing all policies to be taken by the Indonesian government.
\end{abstract}

Keywords: Pancasila, Indonesian Constitutional Law

\begin{abstract}
Abstrak
Dalam perspektif hukum konstitusi, penegasan Pancasila sebagai dasar serta ideologi bangsa dan negara Indonesia sudah sangat jelas termaktub dalam Pembukaan UUD 1945. Tidak perlu lagi dituangkan melalui UU atau Tap MPR, yang kedudukannya suatu saat bisa diubah bahkan dihapuskan. Dengan demikian, pengakuan kedudukan Pancasila yang sudah sangat tegas dan jelas ini membawa konsekuensi bahwa Pancasila harus pula difungsikan sebagai pedoman (dasar dan haluan) dalam menyusun segala kebijkan yang akan diambil oleh pemerintah Indonesia.
\end{abstract}

Kata kunci : Pancasila, Hukum Konstitusi Indonesia 


\section{PENDAHULUAN}

$\mathrm{D}$ alam sebuah peradaban moderen, tidak ada satupun negara yang lepas dari sebuah tatanan berupa norma yang dapat dijadikan pedoman dalam penyelenggaraan negara. Bukan hanya dalam suasana peradaban moderen saja, bahkan ketika negara masih dalam cengkraman penjajah yang berarti belum merdeka tetap negara itu harus memiliki tatatan aturan ${ }^{1}$. Ini dalam rangka untuk mengatur warga negara agar hidup tertib dan ada kepastian dalam bermasyarakat dan bernegara.

Begitupun ketika negara sudah merdeka lepas dari kedaulatan negara penjajah, negara dalam menjalankan penyelenggaraan pemerintahannya tetap harus dipandu oleh sebuah tatanan aturan. Meskipun tatanan aturan itu masih mengadopsi atau memberlakukan ketentuan hukum bekas negara penjajahnya. Demi untuk menghindari adanya kevakuman hukum dan tetap dalam suasana tertib dan damai. ${ }^{2}$

Disadari bahwa dengan ketentuan hukum yang berasal dari negara penjajah belum tentu sesuai dengan jiwa bangsa dan negara itu. Indonesia sebagai salah negara yang berasal dari penjajah juga menyadari hal itu, maka dipandang perlu melakukan perubahan dan menetapkan sebuah tatanan hukum yang sesuai dengan ideologi bangsa Indonesia.

Berdasarkan itulah, maka Indonesia yang telah memproklamirkan kemerdekaannya sejak tahun 1945 harus merumuskan sebuah fondasi tatanan nilai-nilai yang akan diberlakukan. Tatanan nilai-nilai ini harus menjadi ideologi dan pedoman dalam pembentukan hukum dan penyelenggaraan kehidupan berbangsa dan bernegara.

Usaha menuju hal itu telah dibuktikan oleh pendiri bangsa dan negara (founding fathers) Indonesia, ketika menemukan Pancasila sebagai ideologi dan dasar negara. Diharapkan Pancasila dapat menjadi pembeda dengan ideologi negara lain, dan sekaligus sebagai dasar dan pedoman negara dalam melaksanakan sistem pemerintahan Indonesia. Meskipun sejarah lahirnya Pancasila masih sering

1 Hal ini sebuah konsekuensi sebagai negara jajahan yang harus tunduk dan patuh terhadap ketentuan hukum yang diberlakukan oleh negara penjajah.

${ }^{2}$ Dalam konteks pemberlakuan hukum di Indonesia ini disebut aturan peralihan yang ada dalam konstitusi atau UUD 1945, yang intinya menyebutkan bahwa sepanjang belum ada ketentuan hukum yang baru dibuat, maka peraturan perundang-undangan yang ada masih tetap diberlakukan. 
diperdebatkan siapa di antara Bapak Bangsa Indonesia yang menemukan atau penggali nilai-nilai Pancasila. ${ }^{3}$

Dalam uraian tulisan ini tidak bermaksud untuk menjelaskan lebih jauh tentang sejarah lahirnya Pancasila. Akan tetapi hanya fokus menguraikan hal atau tentang kedudukan dan fungsi Pancasila sebagai ideologi dan dasar negara Indonesia, dalam perspekyif atau analisis hukum konstitusi Indonesia. Metode penulisan atau kajian dalam tulisan ini secara sederhana hanya dengan penelusuran berbagai pustaka atau buku yang terkait bahasan fokus masalah utama yang disebutkan di atas.

\section{PEMBAHASAN}

\section{A. Pancasila Sebagai Ideologi Menurut Hukum Konstitusi}

Secara sederhana berdasarkan dari berbagai sumber, terminologi (istilah) ideologi dapat diartikan sebagai ilmu tentang gagasan atau ide-ide. Kemudian pengertian ideologi yang lebih defenitif diberikan oleh Karl Marx yang mengatakan bahwa ideologi sebagai pandangan hidup yang dikembangkan berdasarkan kepentingan golongan atau kelas sosial tertentu dalam bidang politik atau sosial ekonomi. ${ }^{4}$

Pengertian ideologi ini sudah memberikan pemahaman bahwa dalam menjalankan kehidupan bermasyarakat apalagi berbangsa dan bernegara tidak terlepas dari acuan ideologi yang dianut. Secara umum sudah diketahui bahwa peradaban dunia saat ini banyak dipengaruhi dari dua ideologi yang saling bertentangan, yaitu kapitalisme yang liberal dan komunisme yang sosialis. Dua ideologi ini memiliki pandangan atau paradigma yang sangat berbeda dalam membangun sistem penyelenggaraan berbangsa dan bernegara.

Sudah menjadi pengetahuan klasik pula bahwa ideologi kapitalisme banyak diterapkan di negara-negara Barat yang liberal. Kemudian ideologi komunisme diterapkan oleh negara-negara yang sosialis. Meskipun dalam perkembangan globalisasi dewasa ini pasca 'perang dingin' apalagi ketika Uni Soviet sebagai representasi ideologi sosialis mengalami disintegrasi melahirkan banyak negara yang berdiri sendiri, yang menuntut interdependensi atau saling ketergantungan negara-negara, kedua ideologi atau paham ini sudah saling

\footnotetext{
${ }^{3}$ Salah satu buku yang menguraikan kontroversi penggali Pancasila ini dapat dibaca buku yang ditulis oleh S. Silalahi berjudul Dasar-Dasar Indonesia Merdeka Versi Para Pendiri Negara (2001), dalam Bab V Kontroversi Mengenai Pancasila.

${ }^{4}$ Dikutip dari web. Wordpress.com/materi-pelajaran/pancasila sebagai ideologi dan dasar negara.
} 
beririsan. Tidak lagi "an sich" dunia diwarnai dengan dua ideologi saling berhadap-hadapan atau komprontatif satu sama lain.

Kondisi ini harus dimanfaatkan oleh negara Indonesia untuk menanamkan pengaruhnya dengan mengkomunikasikan ideologi yang sesuai dengan jiwa bangsa yang menjunjung nilai-nilai kemanusiaan yang agamis, yaitu Pancasila. Secara substantif nilai Pancasila tergambar di kelima sila-nya yang dilandasi dengan sila pertama yaitu menjunjung tinggi nilai Ketuhanan. Kemudian dijabarkan lagi dengan menghargai nilai kemanusiaan, persatuan, kerakyatan dan ditutup dengan mewujudkan nilai keadilan sosial bagi seluruh rakyat Indonesia.

Lima nilai atau sila yang terkandung dalam Pancasila, dengan tegas dapat dikatakan bahwa Pancasila merupakan ideologi bangsa Indonesia sangat berbeda dengan sistem kapitalisme-liberal dan sosialisme-komunis. Oleh karena Pancasila mengakui dan melindungi baik hak-hak individu maupun hak masyarakat baik dibidang ekonomi maupun politik. Dengan demikian ideologi Pancasila mengakui secara selaras baik kolektivisme maupun individualisme. ${ }^{5}$

Secara sederhana berdasarkan berbagai sumber, hukum konstitusi dapat diartikan sebagai norma atau hukum yang tertulis berisi ketentuan dasar yang mengatur penyelenggaraan sistem pemerintahan suatu negara. Sebagai aturan dasar, maka dalam hukum konstitusi tidak mengatur hal-hal yang sifatnya terinci, tetapi mengatur prinsip-prinsip bagi lembaga-lembaga pemerintahan dalam menjalankan fungsi dan tugasnya untuk mewujudkan tujuan negara tersebut.

Hal ini sesuai yang dikemukakan oleh Jimly Asshiddiqie ${ }^{6}$, bahwa dalam konstitusi sebuah negara hukum harus memuat prinsip-prinsip dalam penyelenggaraan bernegara, baik yang tertulis dalam sebuah naskah undangundang dasar (UUD) ataupun dalam arti tidak tertulis, seperti dalam praktek negara Kerajaan Inggris.

Berdasarkan uraian ruang lingkup hukum konstitusi yang dikemukan oleh Jimly Asshiddiqie, maka Indonesia sebagai negara hukum sudah sangat jelas mencantrumkan prinsip-prinsip penyelenggaran negara oleh lembaga-lembaga negara yang tertuang secara tetulis dalam UUD Negera Republik Indonesia Tahun 1945 (UUD NRI 1945). Termasuk pencantuman nilai-nilai ideologi negara Indonesia. Sudah menjadi konsensus nasional bahwa Pancasila merupakan ideologi Indonesia.

${ }^{5}$ Uraian ini dikutip dari buku Filsafat, Teori, dan Ilmu Hukum oleh Teguh Prasetyo dan Abdul Halim Barkatullah (2012), pada Bab 10 Pancasila sebagai Jiwa Hukum Indonesia.

${ }^{6}$ Hal ini dapat dibaca dalam www.jimly.com, diakses pada 21/12/2017. 
Menurut hukum konstitusi atau UUD 1945 kedudukan Pancasila sebagai ideologi negara Indonesia sebenarnya secara substantif sudah sangat jelas tercantum dalam Pembukaan UUD NRI 1945 atau selanjutnya disebut UUD 1945. Baik sebelum amandemen (perubahan) atau sesudah perubahan, karena yang hanya mengalami perubahan adalah batang tubuh UUD $1945 .^{7}$ Ini dapat dibaca dalam paragraf empat pada alinea-alinea akhir.

Meskipun dalam alinea itu tidak ada sama sekali disebutkan kata 'Pancasila'. Akan tetapi semua rakyat Indonesia sudah mafhum bahwa ada kalimat “..., maka disusunlah Kemerdekaan Kebangsaan Indonesia itu dalam suatu Undang-Undang Dasar Negara Indonesia, yang terbentuk dalam suatu susunan Negara Republik Indonesia yang berkedaulatan rakyat dengan berdasar kepada Ketuhanan Yang Maha Esa..., serta dengan memujudkan suatu Keadilan Sosial bagi seluruh rakyat Indonesia”. Mulai dari kata Ketuhanan Yang Maha Esa, sampai dengan kalimat Keadilan Sosial bagi seluruh rakyat Indonesia, itulah sebenarnya yang dimaksud atau disebut Pancasila. ${ }^{8}$

Jadi perdebatan apakah kedudukan Pancasila perlu ditegaskan kembali melalui sebuah norma hukum dan norma etika, menurut penulis berdasarkan kajian konten analisis (content of analysis) UUD 1945, maka sudah sangat jelas meskipun tidak ada norma hukum (hukum postif, apakah Tap MPR atau UU), Pancasila sudah menjadi ideologi dan selanjutnya dasar negara Indonesia. Apalagi Pembukaan alinea keempat dan UUD 1945 merupakan rangkaian satu paragraf yang utuh yang didalamnya juga dipahami merupakan tujuan Pemerintahan Indonesia dibentuk.

Dalam awal paragraf tersebut sangat jelas disebutkan tujuan membentuk pemerintahan adalah untuk melindungi segenap bangsa Indonesia dan seluruh tumpah darah Indonesia dan untuk memajukan kesejahteraan umum, mencerdaskan kehidupan bangsa, dan ikut melaksanakan ketertiban dunia. Kemudian tujuan ini ditutup dengan kata-kata negara Republik Indonesia harus berdasarkan lima poin prinsip atau nilai, yang mana nilai tersebut dikenal dengan nama lima sila dalam Pancasila seperti yang telah diuraikan di atas.

Kalau penegasan Pancasila ini dituangkan lagi melalui sebuah hukum positif apakah Tap MPR atau UU, malah dapat menimbulkan persoalan. Oleh karena berdasarkan kajian politik hukum, sebuah Tap MPR atau UU bisa jadi

${ }^{7}$ Sejak era reformasi tahun 1998, dalam rentang 4 tahun mulai 1999 - 2002, UUD 1945 telah mengalami 4 kali perubahan.

${ }^{8}$ Hal ini juga dikemukakan oleh S. Silalahi, dalam bukunya Dasar-dasar Indonesia Merdeka Versi Para Pendiri Negara (2001), pada hal. 174 menulis isi naskah Pembukaan UUD 1945. Kemudian mengometari dan mengatakan bahwa "Demikianlah rumusan Pancasila...". 
suatu saat kalau terjadi pergantian pemerintahan, itu bisa diganti bahkan dihapuskan. ${ }^{9}$ Oleh karena secara filosofis substansi nilai Pancasia yang tercantum dalam Pembukaan UUD 1945, bukan dalam batang tubuh UUD, memiliki kedudukan yang sangat strategis. Kalau ada keinginan politik mengubah atau mengamendemen UUD, itu sudah ada kesepakatan nasional bahwa yang bisa diubah adalah hanya batang tubuh tapi isi pembukaan tidak boleh sama sekali dilakukan perubahan. ${ }^{10}$

\section{B. Fungsi Pancasila Sebagai Dasar Negara}

Pengakuan kedudukan substansi Pancasila dalam Pembukaan UUD 1945 sebagai ideologi negara membawa kosekuensi bahwa Pancasila juga harus diakui sebagai dasar negara. Ini sangat berkorelasi, jika tidak dapat dipungkiri lagi bahwa Pancasila sebagai ideologi, maka seyogyanya Pancasila juga harus berfungsi sebagai pedoman dasar dalam penyelenggaraan berbangsa dan bernegara. Pedoman dalam pembentukan tatanan hukum dan termasuk pedoman penyelenggaraan pemerintahan.

Hal ini sangat tegas dikatakan oleh Notonagoro ${ }^{11}$, bahwa ketika Indonesia telah memproklamirkan kemerdekaannya, maka harus dibentuk hukum nasional yang mendasarkan pada UUD. Kemudian UUD itu sendiri dijiwai atau merupakan pengejawantahan nilai-nilai Pancasila. Lebih lanjut Notonagoro menguraikan bahwa Pancasila dapat disebut sebagai Staatsfundamentalnorm ${ }^{12}$ sebagai cita

9 Dalam kajian Politik Hukum, memang dipelajari bahwa produk sebuah regulasi atau peraturan itu sangat tergantung dengan sistem politik pemerintahan. Secara klasik dikenal bahwa UU atau peraturan itu adalah produk politik, karena memang UU dibuat oleh sebuah otoritas yang disebut legislatif yang sumbernya dari partai politik.

10 Ini dapat dlihat ketika UUD 1945 telah mengalami empat kali perubahan, maka yang berrubah adalah batang tubuh UUD tersebut, sedangkan Pembukaan UUD 1945 tidak mengalami perubahan.

11 Pernyataan Notonagoro ini disebutkan oleh Teguh Prasetyo dan Abdul Halim Barkatullah, dalam bukunya berjudul Filsafat, Teori, dan Ilmu Hukum, 2012, hal. 370-371 dan hal. 384 .

12 Menurut penulis istilah inilah biasa disebut sebagai Grundnorm (norma dasar). Jadi sebenarnya pengakuan Pancasila sebagai norma dasar menguatkan alasan bahwa kedudukan Pancasila tidak perlu lagi dikuatkan dalam sebuah UU atau Tap MPR, yang dalam hirarkhi perundang-undangan kedudukannya di bawah UUD 1945, yang mana UUD 1945 merupakan satu rangkain dengan Pembukaan yang didalamnya secara substantif ada nilai-nilai Pancasila. Seperti yang telah diuraikan sebelumnya bahwa meskipun ada kemungkinan UUD bisa mengalami perubahan tetapi Pembukaannya tidak diperkenankan untuk diubah. Inilah makna Grundnorm yang diartikan sebagai norma yang dikategorikan meta-yuridis yang berlaku secara universal. 
hukum (rechtsidee) merupakan bintang pemandu. Ini ingin menjelaskan bahwa posisi Pancasila harus berfungsi sebagai pedoman dalam pembentukan hukum positif serta dapat digunakan untuk menguji hukum positif. Dengan demikian penempatan Pancasila sebagai Staatsfundamentalnorm, maka pembentukan, penerapan, pelaksanaannya tidak dapat dilepaskan dari nilai-nilai Pancasila.

Dengan uraian penjelasan ini, maka tidak dapat diragukan lagi bahwa fungsi Pancasila harus dijadikan dasar dan haluan dalam menyusun segala kebijkan di Indonesia, baik dalam bidang ekonomi, politik, dan pembangunan sumber daya manusia. Serta tentu juga Pancasila harus difungsikan sebagai sumber dari segala sumber hukum. Artinya dalam pembentukan segala aturan hukum yang kelak akan diberlakukan sebagai hukum positif, harus mencerminkan nilai-nilai atau kelima sila yang terkandung dalam Pancasila yang secara subtantif ada dalam alinea keempat Pembukaan UUD 1945.

\section{PENUTUP}

Simpulan dari uraian bahasan tulisan singkat dan sederhana ini adalah bahwa dalam perspektif hukum konstitusi, penegasan Pancasila sebagai dasar serta ideologi bangsa dan negara Indonesia sudah sangat jelas termaktub dalam Pembukaan UUD 1945. Sehingga tidak perlu lagi dituangkan melalui UU atau Tap MPR, yang kedudukannya suatu saat bisa diubah bahkan dihapuskan. Dengan demikian, pengakuan kedudukan Pancasila yang sudah sangat tegas dan jelas ini membawa konsekuensi bahwa Pancasila harus pula difungsikan sebagai pedoman (dasar dan haluan) dalam menyusun segala kebijkan yang akan diambil oleh pemerintah Indonesia. 


\section{DAFTAR PUSTAKA}

Sekretariat Jenderal dan Kepaniteraan Mahkamah Konstitusi Republik Indonesia, 2010. Undang-Undang Dasar Negara Republik Indonesia Tahun 1945 dan Undang-Undang Republik Indonesia Nomor 24 tahun 2003 tentang Mahkamah Konstitusi

S. Silalahi, 2001. Dasar-dasar Indonesia Merdeka versi Para Pendiri Negara, PT. Gramedia Pustaka Utama, Jakarta

Teguh Prasetyo dan Abdul Halim Barkatullah, 2012. Filsafat, Teori, dan Ilmu Hukum Pemikiran Menuju Masyarakat yang Berkeadilan dan Bermartabat, PT. RadjaGrafindo Persada, Jakarta.

Website: Wordpress.com/materi-pelajaran/pkn-kls-8/pancasila sebagai ideologi dan dasar negara, diakses: 24/03/2017

Website, Www.Jimly Asshiddiqie.Com; diakses 21/12/2017 